\title{
ESG Disclosure and Firm Value: Family versus Nonfamily Firms
}

\author{
Annisa Meidiana Thahira, Aria Farah Mita
}

Department of Accounting, Universitas Indonesia, Depok, Indonesia

*Corresponding author. Email: aria.farahmita@ui.ac.id

\begin{abstract}
This research is motivated by the increasing demand for environmental, social, and governance (ESG) disclosure. This phenomenon raises questions as to whether this information is properly used and provides benefits to the company that published the disclosure. Several studies attempted to observe the cost-benefit of ESG disclosure; however, most of them focused on developed countries. Therefore, this study expands the sample to five developing countries in ASEAN. The benefits to be examined in this study are related to the value of the firms. ESG disclosure can enhance firm value because it provides an understanding of important aspects related to company activities, allowing the investor to identify the best-managed companies and assign a premium value for those companies. Based on this explanation, we expect that ESG disclosure will have a positive association with firm value. The effect of the ownership structure on the benefit from ESG disclosure is also analyzed in this study. The difference between family and nonfamily firm characteristics is why this analysis is important. As we know, family firms have greater information asymmetry than nonfamily firms, and this condition is related to a higher level of disclosure in family firms. Therefore, we expect that family firms will have better ESG disclosure and enhance the benefit of such disclosure to these firms. Our final sample includes 390 firms in the five ASEAN countries with the complete required data in Thomson Reuters Datastream. We collect all required data in dollar currency and use a least square regression model to analyze these data. Based on the result of the study, the conclusion reached is that ESG disclosure has a positive association with firm value. However, the association is lower for family firms than for nonfamily firms. These results show that disclosing ESG information provides some benefits for the company because it helps investors make better decisions and improve their confidence in the company.
\end{abstract}

Keywords: ESG Disclosure, Firm Value, Family Firms, Ownership Structure

\section{INTRODUCTION}

During the past decades, the demand for nonfinancial disclosure has increased. This phenomenon was based on the loss of relevance of financial statements because of the financial crises, renumeration scandals, and suspicions about the social and environmental implications of business activity. Transparency of corporate behavior is needed by investors and can be obtained through nonfinancial disclosure (Orlitzky et al., 2003).

One type of nonfinancial disclosure is disclosure that discusses environmental, social, and governance issues, which is referred to as ESG disclosure. The impact of these three aspects has become the concern of society and other stakeholders (Baron, 2014). The company is required to take responsibility for any mistakes that can happen regarding those aspects, such as epidemics that arise from improperly disposed factory waste, depletion of natural resources, climate change, poor working conditions, and corporate scandals (Baldini, 2018). ESG disclosure is important because it can describe internal processes and changes related to company strategies, company resilience, and contributions to society (Baron, 2014).

Questions then arise regarding this nonfinancial disclosure, such as "is the information from a company's nonfinancial disclosure used?" and "if so, what benefit does the company get from the use of that information?" Several studies attempted to answer these questions, but most focused on developed countries. Therefore, this study attempts to analyze the benefit of nonfinancial disclosure in developing countries to provide additional insights into this type of disclosure. 
In addition to using samples with different institutional factors from most previous research, this study also examines the differences in the benefits of this disclosure between family and nonfamily firms. This examination is expected to be interesting because the characteristics of those companies are different, indicating that the result is expected to be different (Holthausen, 2009).

This study aims to analyze whether ESG disclosure will provide benefits to the company that publishes such disclosures based on the value of the company and whether the benefits are higher for family firms than nonfamily firms. We expect that ESG disclosure can enhance firm value because it provides an understanding of important aspects related to company activities. This understanding allows the investor to identify the bestmanaged companies to give them a premium value. This impact will be higher for family firms because they use ESG disclosure as a legitimation tool and to gain investors' trust to ensure that the disclosure is of better quality and will provide better results. This study use signaling theory and legitimation theory as a basis for developing the hypothesis.

\section{THEORETICAL FRAMEWORK AND DEVELOPMENT OF HYPOTHESES}

\subsection{Signaling Theory}

Signaling theory fundamentally discusses the effort to reduce asymmetry among interested parties for this case between the company insider and its stakeholders (Spencer, 2002). The company publishes information publicly, enabling the stakeholders-especially investors - to understand as much as possible about the company. Information disclosure, which is a signal for stakeholders, is very important because it affects the appraisal and decision-making process by related parties. As explained by Arkelof (1970), limited information leads to a biased judgment toward the company's actual ideas and conditions. One example is that investors cannot objectively assess whether the company has a high risk from their dangerous operational activities and cannot survive for a long time because of this risk.

ESG disclosure is one example of the company's efforts to signal its stakeholders, especially investors. This signaling is related to the pressure that the company feels from stakeholders to behave in a socially responsible manner (Grougiou et al., 2016). Through disclosure information, companies want to show that they have a motive for sustainability and ethics. The impact of this disclosure that a company expects is that the investor can precisely assess the company's risk related to its prospects (Brigham and Houston, 2011).

\subsection{Legitimation Theory}

The organization, in this case, the company attempts to establish conformity with social values and behavioral norms that are accepted in the social groups that the company joins. This conformity is the company's way to justify its existence in the group and to continue all of its activities (Maurer, 1971). This explanation forms the basis of legitimacy theory; that is, companies can only survive if stakeholders believe that it operates according to their expectations. ESG disclosure is then considered to be a tool for companies to show that they have social awareness and behave in accordance with stakeholders' expectations (Baldini et al., 2018).

\subsection{Characteristics of Family Firms}

One characteristic of family ownership is the tendency of shareholders - who are family membersto have more information than minority shareholders (Chau and Gray, 2010). Agency problems between managers and family owners do not occur because the owners regularly engage in daily activities to have more information and control managers more effectively (Chen et al., 2008).

However, other agency problems arise, as explained by Chau and Gray (2010). This condition makes minority investors think that investing in family firms has a higher risk because determining whether the company has issues that will damage its future profits is difficult (Martinez-Ferrero, 2018).

\subsection{Previous Research}

Several studies analyzed the effects of disclosing ESG information to the company, such as the effect on performance and corporate value. Atan et al. (2016) analyzed the effects of ESG disclosure on company performance in Malaysia. Unfortunately, the study failed to find a positive effect of ESG disclosure on performance. In contrast to the results found by Atan et al. (2016), Li et al. (2018), Buallay (2018), and Chauhan and Kumar (2018) found that ESG disclosure has a positive relationship with the company's performance and value.

The effect between ESG disclosure and company value is also influenced by the ownership structure. Some studies attempted to examine the impact of family ownership structures on the benefits of disclosing nonfinancial information-in this case, sustainability disclosure - to companies. A recent study is Nekhili et al. (2018), which found that family ownership structures reinforce the positive relationship between CSR disclosure and company value. 


\subsection{Hypotheses Development}

According to Healy and Palepu (2001), company disclosures play two important roles in facilitating economic resource allocation. The first role is to enable investors to assess investment opportunities in related companies and increase the accuracy of their valuations. The second role is to assist investors in controlling company managers. Therefore, regulators require companies to issue various forms of information. Based on Chauhan and Kumar (2018), the benefits of disclosure can be achieved as long as the information provided is a match with investors' needs. The information needs to be suitable to ensure that the benefits from disclosing this information can be accessed by the company and its stakeholders.

The disclosure of ESG information is beneficial for the company. Nielsen Global Survey of Corporate Social Responsibility (2014) conducted a survey that showed that more than $50 \%$ of global consumers are willing to pay more for products and services from companies that are socially and environmentally responsible. Information on a company with those types of responsibility can only be obtained through disclosures made by the company. Therefore, ESG disclosure will be useful for the company.

In addition, many in portfolio management use ESG information as the basis for identifying companies in which to invest. Investors can identify the current and future profits of the company and analyze its management process (Chauhan and Kumar, 2018). Based on this identification, ESG disclosures are expected to help investors understand the company's valuation and the intentions of its founders. Therefore, investors will want to provide premium value to companies that disclose more nonfinancial information.

Based on these explanations, the following research hypothesis is developed.

H1: A positive relationship exists between ESG disclosure and company value.

Stakeholder responses to the reliability of CSR communication relate to their trust in companies that disclose information (Elving, 2013). Family firms are different from nonfamily firms in terms of their relationships with investors and other stakeholders. The difference, as previously explained, is the high information asymmetry between majority investors and minority investors. Martinez-Ferrero et al. (2018) subsequently found that greater information asymmetry was associated with higher voluntary information disclosure.

Voluntary disclosure, in this case of ESG, requires greater effort by family firms so that their image and reputation are maintained and kept from the perception that their minority investors are more vulnerable to exploitation (McGuire et al, 2012). Salvato and Mellin (2008) also found that family firms will attempt to build and manage strong relationships with external and internal stakeholders more often through good disclosure of nonfinancial information. The disclosure of voluntary nonfinancial information, in this case of ESG, is superior and expected to positively influence the perceptions of investors and other stakeholders (Chauhan and Kumar, 2018).

Based on these explanations, the following research hypothesis is developed.

H2: The positive relationship between ESG disclosure and firm value is stronger for family firms than nonfamily firms.

\section{RESEARCH METHODOLOGY}

\subsection{Data and Sample}

The population in this study is comprised of companies listed on the ASEAN 5 Stock Exchange (Indonesia, Malaysia, Philippines, Singapore, and Thailand) during 2014 until 2016. The sample criteria used are companies (1) with a complete ESG combined score during the period; and (2) that have all of the required financial data. The data are obtained from Thomson Reuters and company annual reports. The final sample includes 390 companies.

\subsection{Research Model}

The research model used to test the hypothesis follows Chauhan and Kumar (2018):

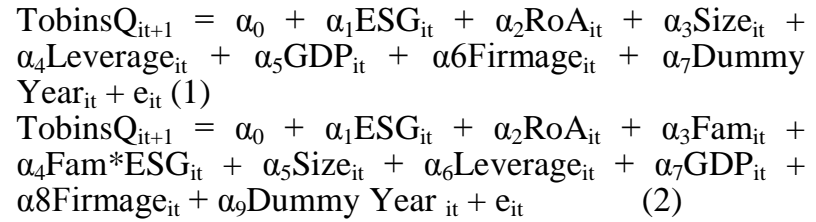

where Tobins $Q_{i t}$ is firm value $t+1$; ESG is the ESG combined score; Fam takes the value of 1 if the firm is family-owned; RoA is net income after taxes divided by total assets; Size is total assets; Leverage is total debt divided by total equity; Age is the number of years since the firm's incorporation; and GDP is gross domestic product for each country.

\section{RESULT}

\subsection{Sample and Descriptive Statistics}

This study uses the sample of public companies in the ASEAN 5 during 2014 until 2016. Table 1 shows the descriptive statistics for all samples. 
Table I. Descriptive Statistics

\begin{tabular}{|l|c|c|c|c|}
\hline & Mean & $\begin{array}{c}\text { Standard } \\
\text { Deviation }\end{array}$ & $\begin{array}{c}\text { Mini- } \\
\text { mum }\end{array}$ & $\begin{array}{c}\text { Maxi- } \\
\text { mum }\end{array}$ \\
\hline TobinsQ & 1.96 & 2.09 & 0.53 & 21.31 \\
ESG & 48.51 & 16.59 & 11.16 & 89 \\
Family & & 0.49 & 0 & 1 \\
Owner- & 0.38 & 1.10 & 19.27 & 24.95 \\
ship & 22.18 & 1.72 & 0.004 & 21.76 \\
Size & 1.07 & 0.08 & -0.13 & 0.75 \\
Leverage & 0.07 & & & \\
RoA & 16949 & 20517.97 & 2842.94 & 56957.08 \\
GDP & & & & \\
Age & 20.72 & 11.69 & 1 & 68 \\
\hline
\end{tabular}

\subsection{Hypothesis Testing Results}

The result of the model regression in Tables 2 and 3 indicate that the model is statistically significant, as shown by the probability F-statistic of 0.0000 . The results indicate that the ESG coefficient is positive and significant, meaning that ESG disclosure causes a significantly higher firm value. Thus, hypothesis (H1) is supported. From this results, we can know that ESG disclosure can be used as a information signal and tools to get the a legitimation by the company. Unfortunately, the result for $\mathrm{H} 2$ shows that family ownership weakens the relationship between ESG disclosure and firm value, which differs from expectations.

\section{CONCLUSION}

The results indicate that ESG disclosure has a positive relationship with firm value. The better the disclosure, the higher the firm value. Unfortunately, this positive relationship is weakened for family firms. Based on these results, we conclude that disclosing ESG information provides some benefits for the company because doing so helps investors make better decisions and improve their confidence in the company.

\section{REFERENCES}

[1] Akerlof, G. A. (1970). 'The market for "lemmons": quality uncertainty and the market mechanism.' The Quarterly Journal of Economics, 84(3), pp. 488-500, https://doi.org/10.2307/1879431.

[2] Atan, R., Razali, F. A., Said, J., and Zainun, S. (2016). 'Environmental, social, and governance (ESG) disclosure and its effect on firms's performance: A comparative study.' International Journal of Economics and Management, 10(52), pp. 355-375.
[3] Baldini et al. (2018). 'Role of country- and firmlevel determinants in environmental, social, and governance disclosure.' Journal of Business Ethics, 150(1), 1-20, https://doi.org/10.1007/s10551-016$3139-1$.

[4] Baron, R. (2014). 'The evolution of corporate reporting for integrated performance.' Paris: OECD. www.oecd.org.

[5] Brigham, E. F., and Houston, J. F. (2011). Essential of management, $11^{\text {th }}$ edition. Hourcort College, United States of America.

[6] Chau, G., and Gray, S. J. (2010). Family ownership, board independence, and voluntary disclosure: Evidence from Hongkong. Journal of International Accounting, Auditing, and Taxation, 19(2), 93-109.

[7] Chauhan, Y., and Kumar, S. B. (2018). 'Do investors value the nonfinancial disclosure in emerging markets?.' Emerging Markets Review, 37, pp. 32-46. https://doi.org/10.1016/j.ememar.2018.05.001.

[8] Elving, W. (2013). 'Scepticism and corporate social responsibility communications: The influence of fit and reputation.' Journal of Marketing Communication, 19(4), pp. 277-292, https://doi.org/10.1080/13527266.2011.631569.

[9] Grougiou, V., Dedoulis, E., and Leventis, S. (2016). Corporate social responsibility reporting and organizational stigma. The case of "sin" industries. Journal of Business Research, 69(2), pp. 905-914.

https://doi.org/10.1016/j.jbusres.2015.06.041.

[10] Holthausen, R. W. (2009). 'Accounting standards, financial reporting outcomes, and enforcement.' Journal of Accounting Research, 47(2), pp. 447458 , https://doi.org/10.1111/j.1475679X.2009.00330.x.

[11] Martinez-Ferrero., J, Rodriguez-Ariza, L., GarciaSanchez, I-M., and Cuadrado-Ballesteros, B. (2018). 'Corporate social responsibility disclosure and information asymmetry: The role of family ownership.' Review of Managerial Science, 12(4), pp. 885-916. https://doi.org/10.1007/s11846-0170232-5.

[12] Maurer, J.G. (1971). Readings in organization theory: Open-system approaches. New York: Random House.

[13] McGuire, J., Dow, S., and Ibrahim, B. (2012). 'All in the family/Social performance and corporate governance in the family firm.' Journal of Business 
Research, 65(11), pp. 1643-1650. https://doi.org/10.1016/j.jbusres.2011.10.024.

[14] Orlitzky, M., Schmidt, F. L., and Rynes, S. L. (2003). 'Corporate social and financial performance: a meta-analysis.' Organization Studies, 24(3), pp. 403-441, https://doi.org/10.1177/0170840603024003910.
[15] Salvato, C., and Melin, L. (2008). 'Creating value across generation in family-controlled businesses: The role of family social capial.' Family Business Review, 21(3), pp. 259-276. https://doi.org/10.1177/089448865080210030107.

[16] Spencer, M. (2002). 'Signaling in retrospect and the informational structure of markets.' American Economic Review, 92, pp. 434-459, https://doi.org/10.1257/00028280260136200. 